\author{
St ud i a P ilosophic a \\ Wratis lavi e n s i a \\ vol. XIV, fasc. 1 (2019) \\ DOI: $10.19195 / 1895-8001.14 .1 .10$
}

\author{
DARIO MAZZOLA \\ ORCID: 0000-0003-4143-7316 \\ State University of Milan
}

\title{
Is Free Movement a Natural Right? Between Modern State and Aristotelian-Thomist Utopias
}

\begin{abstract}
In these times of walls and razor-wires, open borders appear to be more utopian than always. Nonetheless, philosophers like Joseph Carens and, similarly but earlier, Timothy King and James L. Hudson, famously argued that the major philosophical perspectives in the Western world-libertarian, egalitarian, and utilitarian - would support a right to freedom of international movement of people. What would be the relative default position from the standpoint of natural law theory? In this article, I present a general introduction on natural law theory and its role in and outside philosophy, before presenting claims specific to the migration debate. I then recall the defence of a right to free movement by two authors sympathetic to the natural-law tradition, Ann and Michael Dummett: a defence which is grounded in principles of fairness and reciprocity and develops elements belonging to international law. I also outline John Finnis's more critical and nuanced position. Finnis is eager to legitimize state authority and the "special relations" binding fellow countrymen: however, I claim that the classic Thomist perspective in which he situates these claims ensure his respect of a right to international movement which could be characterized as a version of "open borders," with some definitional restrictions and qualifications of this latter phrase. Finally, I deal with the theory of Alasdair MacIntyre. Trying to infer MacIntyre's attitude toward migration from the classic but short article on patriotism, might turn out to be no less difficult than potentially misleading, especially if that article is not read in its details. Complementary elements are offered in MacIntyre's account of natural law "as subversive." On these grounds, I claim that, contrary to simplistic misreading of MacIntyre's alleged "communitarianism," MacIntyrean Aristotelian Thomism would endorse a theory of migration more compatible with reasonably
\end{abstract}


conceived open borders. I conclude my chapter with a presentation of Aquinas's concise intervention on the subject, and I show that it further supports my reading of the natural law tradition.

Keywords: natural law, state authority, free movement, patriotism

\subsection{Introduction: The Elusive Definition of the Natural Society}

Supporters of cultural homogeneity and immigration restrictions are sometimes accused of a wish to "go back to the Middle-Ages." Pre-modern societies are often considered hostile to foreigners and closed to an extent that is unacceptable to contemporary standards. Yet, if one considers the comparison more attentively, some complications arise.

The first is that differences between contemporary and ancient societies are not limited to morality or philosophy but reach so deeply into institutional and social structures that the terms "state" and, more importantly, "immigration" hardly retain the same meaning in all contexts. The nation-state is a recent invention, and the effective administrative, legal, and technological bureaucratic apparatus which is necessary for contemporary migration control simply did not exist until very recently. Even the indisputable point that technological and economic improvements have widened the possibility to move is to be qualified since the same improvements help to constrain and control movement as well - for instance by introducing scanning of ID codes and easily verifiable national currencies. Without drones and cars, borders were not as "easy" to guard, nor was Hadrian's Wall, one of the most famous guarded fortifications in history, as impregnable as Ceuta and Melilla.

This outline of the historical and social background leads to a second consideration: the philosophers of ancient and medieval "communities" were not necessarily more hostile to migration than present-day ethicists. Aristotle, who, it is to be remembered, was himself for a long time an "immigrant" from Macedonia to ancient Athens - that is, to the eyes of many Athenians, a "barbarian"-and Aquinas, who spent his life travelling and working in a diversity of kingdoms and territories, and during one such "international" trip died in 1274, both make references to immigration which do not sound especially restrictive. If they do not treat more extendedly the issue, it seems even possible to doubt that at the time, in the absence of a strong legal presupposition in favour of national sovereignty - it was even less problematic than nowadays.

Be that as it may, from Aristotle's explicit attempt at defining a political community by reference to its constitution rather than ethnicity ${ }^{1}$ on to more recent interventions, natural law tradition has developed a host of relevant and unsuspected insights over migration.

${ }^{1}$ J. Finnis, "Nationality and Alienage," [in:] J. Finnis, Human Rights and Common Good, Oxford 2011, p. 146. Finnis claims that Aristotle fails in that fundamental enterprise. 


\subsection{Natural Law, Immigration, and General Culture}

Claims such as "All nations include a portion of immigrants," "All societies restricted membership," "It is natural to associate with people of one's own kind," and all the more claims on the importance of ethnicity and blood-ties, often presuppose or even expose a reference to questions of nature, universality of customs, and of their normativity. Ann Dummett recalls a very concise definition of natural law offered by Edmund Burke as "That law that governs all laws" and stresses its universal and egalitarian character. Every human being can indeed apprehend its precepts in conscience, and this objective, the pre-political legislation would surpass all statutes in authority. ${ }^{2}$ Natural-law standpoints are often proposed as among the most favourable to open borders, but as it will be shown, the generality of Burke's and Dummett's definition embraces a variety of positions, sometimes significantly different, that have impacted Western thought along centuries. Thus, before turning to a more specifically philosophical characterization, I would rather stress its importance to general culture and especially to legal reasoning and practice. It seems to be clear, however, that neither in philosophy and legal theory, nor more generally, one can speak of "natural law theory" as if it were a unitary and coherent school.

An appeal to natural law is frequently found in legal theory and jurisprudence, especially in the Anglophone world: some of the "founding fathers" of modern states, most evidently in the United States, ${ }^{3}$ professed their creed in "the Laws of Nature and of Nature's God," as written in the introduction to the Declaration of Independence, as the fundamental ideal on which to build a society. Natural law is thus presented as the touchstone with which the overall political constitution, and the individual statutes stemming from it, are to be confronted and evaluated. An appeal to natural law, in judicial review, has commonly the purpose to qualify, restrict, or contest an act by the legislative power. Justice Andrew P. Napolitano does precisely that when he claims:

$[T]$ he freedom to travel is a fundamental natural right. This is not a novel view. In addition to Aquinas and Jefferson, it has been embraced by St. Augustine, John Locke, Thomas Paine, Martin Luther King Jr., Pope John Paul II and Justice Clarence Thomas. Our fundamental human rights are not conditioned or even conditionable on the laws or traditions of the place where our mothers were physically located when we were born. Stated differently, we all possess natural rights, no more and no less than any others. All humans have the full panoply of freedom of choice in areas of personal behavior protected from governmental interference by the natural law, no matter where they were born. ${ }^{4}$

2 "The Transnational Migration of People Seen from within a Natural Law Tradition," [in:] Free Movement: Ethical Issues in the Transnational Migration of People and Money, B. Barry, R.E. Goodin (eds.), London-New York 1992, p. 169.

${ }^{3}$ For a synthesis on the influence of natural law in the US context, see for instance R.S. Barker, "Natural Law and the United States Constitution," The Review of Metaphysics 66 (2012), pp. 105-130. Barker synthetically characterizes the natural law as "the idea that God, in creating the universe, implanted in the nature of man a body of Law to which all human beings are subject, which is superior to all manmade law, and which is knowable by human reason" (p. 105).

4 A.P. Napolitano, "Immigration as a Natural Human Right," The Washington Times, 31 January 2013, https://www.washingtontimes.com/news/2013/jan/31/immigration-as-a-natural-human-right/ (accessed: 30.08.2018). A similar view is expressed by J. Klesney on the website of the Acton Institute: 
This "subversive" ideal of natural law as not only regulating matters of state legitimacy and secession - as in the Declaration of Independence - but also as enshrining areas of individual immunity, is deeply seated in the history of political thought. Chandran Kukathas makes what can be seen as an addition to Napolitano's list when he recalls that:

The moral world of ancient Greece described in Homer's poetry is undoubtedly a long way away from our own. Yet there is something important, nonetheless, about the idea that hospitality and the treatment of strangers is fundamental to civilized life, and the key to the possibility of a well-ordered society. It does not seem out of place in Sa'di's thirteenth century Persia; or, for that matter, in our own time. It seems right to say that we owe a duty of hospitality to strangers, particularly when they come to us in distress: and we owe the most when they can offer us the least. "For I was an hungred, and ye gave me meat: I was thirsty and ye gave me drink: I was a stranger, and ye took me in." ${ }^{5}$

There are at least two common features between the two records. The first is intentional and emphasized diversity of the cultural contexts they refer to. Ancient Greece, Medieval Persia, Modern Britain, and others are some of the places supporters of a right to move have inhabited over thousands of years. This is consistent with Ann Dummett, and in general natural law thinkers, claiming that

In medieval Europe, the primacy of natural law was taken for granted, and no authority was entitled to obedience which was not assumed to derive its power therefrom. But the concept was not a Christian creation: Cicero and later Roman Jurists based their arguments upon a universal, natural law. Outside Europe, similar concepts are found in Hindu and Taoist systems of thought. ${ }^{6}$

The variety of historical examples is also indispensable to satisfy another requirement proposed by Ann Dummett: "When discussing rights, it is important to stand back from the situations particular to certain times and places and test one's theory against a variety of circumstances."7

A second noticeable feature is the mixture of religious and non-religious sources. Besides its influence on law, the natural law tradition has had a longstanding impact on religious ethics and on Christian and Catholic teachings in particular. In its reworking by Aquinas and other similar versions, up to people writing in these very days, natural law is not seen as a fruit of the sole Judeo-Christian tradition: Aquinas's sources are, for instance, classics such as Plato and Aristotle. Thus, natural law is presented, even from within this religious tradition, as a coherent body of laws and precepts which can be attained by reason alone, and these norms are proposed as valid for humanity at large. For instance, The Catholic view on migration is explicit: in the Catholic Catechism (2241) there is the mention of a qualified right to immigration, complementary to the right to emigration sanctioned by international charters, not on grounds of Christian charity, but of political justice. Even before the II Vatican Council, Pius XII publicly defended "the natural right of the person not to be impeded while immigrating or emigrating, under the pre-

"Migration Rights, Natural Law, and the Free Society": https://acton.org/pub/commentary/2000/11/27/ migration-rights-natural-law-and-free-society (accessed: 21.06.2017).

${ }^{5}$ Ch. Kukathas, "Are Refugees Special?," [in:] Migration in Political Theory, L. Ypi, S. Fine (eds.), Oxford 2016, p. 250. The final quote is from Matthew, 35:25.

${ }^{6}$ A. Dummett, "The Transnational Migration of People," p. 169.

7 Ibid., p. 178. 
text of a common good falsely understood or applied." Since the Jewish, and Muslim religions too originated in a context, the Arabian Peninsula, where nomadic life was common, and hospitality has historically been a value as sacred as vital, it is no surprise that in general they all vocally defend the rights of migrants. ${ }^{9}$

\subsection{Two Versions of Natural Law}

The very vast and diverse outline of natural law views which can be derived from world cultures becomes even more complicated when analyzed philosophically and historically. For, if on the one hand, it is apparent that modern thinkers relied on the idea of natural law very frequently, it is on the other hand indisputable that they did so in a manner very different from the classics, especially by changing, reducing, omitting or suppressing metaphysical and theological presuppositions.

A telling example comes from a modern intervention on the theme of naturalization: David Resnick characterizes the political conception on which John Locke justifies the absorption of foreigners as reflecting a "new concept of individualistic voluntaristic citizenship which provides an alternative to the common law notions of natural allegiance of Locke's day."10 The argument for massive naturalization, in that case, would be that "People are the strength of any country or governm[en]t this is too visible need proof."11 In this modern conception, that is, the one to be found in accounts of natural law developed from Hobbes through Locke to Kant, "individualistic voluntaristic" and humanistic aspects stand out as clearly different from a theory like the Aristotelian, which was, so to speak, "directly natural." Naturality is now mediated by the artificiality of the state. And, as the term "humanistic" is meant to emphasize, the accent is more on natural law as constituted by sovereign human reason, with a much greater subjective element than in Aquinas's moderate realism. ${ }^{12}$ John Finnis even proposes the precise symbolic breakthrough of 1660, when Samuel Pufendorf published his Elements of Universal Jurisprudence, and claims that the core distinction between modern and classical natural law theorists would be the abandonment of the attempt at knowing the final ends to derive norms from them. ${ }^{13}$ The authors I am now to turn to are mostly relying on the classical natural law tradition: and yet, I would claim that in contempor-

${ }^{8}$ Pius XII, "Radiomessaggio di sua Santità Pio PP. XII per il Santo Natale" [Christmas message 1952], https://w2.vatican.va/content/pius-xii/it/speeches/1952/documents/hf_p-xii_spe_19521224_ natale.html (accessed: 30.08.2018). My own translation.

${ }^{9}$ See E.W. Collier, Ch.R. Strain (eds.), Religious and Ethical Perspectives on Global Migration, New York 2014.

${ }^{10}$ D. Resnick, "John Locke and the Problem of Naturalization," The Review of Politics 49 (1987), p. 368 .

11 J. Locke, For a General Naturalization, 1693, unpublished appendix, quoted ibid., p. 385.

12 Aquinas's realism is discussed in A. MacIntyre, The Tasks of Philosophy: Selected Essays, vol. 1, Cambridge 2006, especially in chapter 9: "Philosophy Recalled to its Tasks: A Thomistic Reading of Fides and Ratio," p. 179 ff.

13 J. Finnis, "Natural Law: The Classical Tradition," [in:] The Oxford Handbook of Jurisprudence and Philosophy of Law, J.L. Coleman, K.E. Himma, S.J. Shapiro (eds.); online publication date: 2012, doi:10.1093/oxfordhb/9780199270972.013.0001; see in particular pp. 5-7. 
ary accounts of natural law influences from the more recent strand are usually detectable, for instance in Finnis's statism or Ann Dummett's considerations on international law.

\subsection{Natural Law Philosophical Perspectives on Migration}

If the research is then restricted to the classical understanding of natural law tradition revived in contemporary accounts, the number of sources is much reduced. Ann Dummett takes up the task of offering a natural law point of view on migration in her already quoted essay, while Paul J. Weithman inquiries into the implications of natural law theory for global justice and redistribution. Finnis advances critical comments on both. ${ }^{14}$

In reality, neither Ann Dummett nor Weithman make organic references to the natural law tradition, authors, and arguments, and this is part of the ground for Finnis' criticism. Ann Dummett seems to argue mainly on two bases: history and international law. Her claims are that, historically, the general presupposition was that every person was entitled to migrate unless there were specific reasons on the state's side to restrict movement. She does not dispute the validity of the principle of international sovereignty, even if, she holds, when considering the international community, it would be more fitting to speak of independent and equal states: sovereignty is exercised over citizens. Sovereignty - or independence - are not excuses to an arbitrary exercise of power, especially if this is done to restrict an individual's choices. Thus, the modern presumption in favour of state selection of potential immigrants is not granted, unless there is evidence of the risk of their entrance infringing on other individuals' human rights. We should, Ann Dummett argues, return to the more open conception of state borders that was in place until about the end of the 19th century: unsurprisingly, in coincidence with the less tense international relations during Belle Époque.

A similar conception is also implied by the international law guarantee of rights to move freely within and out from one's country: rights which are similar to, or complementary with, the right to international emigration. According to Ann Dummett, the implications of such rights are not spelt out in international law only because of the West's hypocritical interest in using it as a means to world hegemony: she successfully foresees - the essay was written during the collapse of the Soviet Union - that the liberal states' attitudes would have been proved insincere when the number of migrants would have skyrocketed. Paradoxically enough, the West's insistence on freedom of movement was conditional on its restriction by the East. Ann Dummett finally invokes the acceptation of a right to migrate as a first step towards its implementation.

Ann Dummett's methodology and substantial points converge with those advanced by her husband Michael Dummett in his pamphlet On Immigration

${ }^{14}$ See B. Barry, R.E. Goodin (eds.), Free Movement, chapters 12-14, "Natural Law Perspectives." 
and Refugees. ${ }^{15}$ Michael Dummett advances arguments that seem to be entirely compatible with a natural law ethical conception, but he claims to be searching for a "rigorous" argument, not a technical one. ${ }^{16}$ Indeed, he does not make reference to natural law tradition and theoretical presuppositions either, with some notable exceptions. Besides, once again, human rights and international law, Michael Dummett relies on empathy and on reciprocity arguments based on the "golden rule." In this sense, both accounts seem to be compatible with Carens's, as explicitly claimed by Ann Dummett with reference to "Aliens and Citizens: A Case for Open Borders." 17 Michael Dummett's argument is divided into two parts: he begins by deriving principles from common-sense morality applied to migration, and then presents a critical history of the British immigration laws and practices, along with reviews of a few other states. He and Ann were both life-long campaigners and activists and the philosophical, moral, and legal claims they advance are often not detached from such standpoints. Yet the overall account's reasonability is difficult to resist: Michael Dummett proposes to adopt the principle of a qualified, non-fundamental right to free movement, as such subordinated to other more vital human rights and to their ordinary qualifications, such as public order and even a right "not to be overwhelmed." 18 Michael Dummett, however, is keener to apply such restraints to small countries in actual danger of being "swamped" rather than to bigger ones which in reality register a 2 to $5 \%$ immigrant population: these and other realist(ic) concerns are scattered throughout the book. ${ }^{19}$ Even more realistically, the historical part of his argument casts light on how migration is intertwined with colonialism, and immigration restriction to racism. The complex legal reformation and reformulation of British citizenship and nationality have oftentimes served, according to him, as an ideological mask which through geographical and jurisdictional distinctions is meant to exclude from the right to free movement within the Commonwealth all the people of an undesired race. Therefore, he claims that to resist such egoistic and immoral nationalism, migration and refuge should be governed by reformed UN bodies. His and Ann's accounts seem thus perfectly compatible not only with Carens's, but with the emerging global governance of migration as well.

A rather different view seems to be offered by Finnis. In his comment on Ann Dummett's contribution, Finnis does not take position over "what is just and what unjust in the international movement of people." And yet, he criticizes Ann Dummett and Weithman for oversimplifying the theory. However, and here most interestingly, he specifies that it would be wrong to infer that the policies he favours

${ }^{15}$ M. Dummett, On Immigration and Refugees, London 2001.

16 Ibid., p. XII.

17 A. Dummett, "The Transnational Migration of People," p. 177: "I think Carens' view can be justified in the terms of natural law principles."

18 M. Dummett, On Immigration and Refugees, p. 52.

${ }^{19}$ In this respect I find Michael Dummett's approach to be convergent with the more explicitly realistic view taken by D.C. Hendrickson, "Migration in Law and Ethics: A Realist Perspective," [in:] Free Movement, pp. 213-231. 
"require less far-reaching reforms than theirs." 20 What can these policies be? We are unfortunately left with no definite answer. Finnis does not present his claims in terms of rights, ${ }^{21}$ in the context of free movement and elsewhere, and does not assume the label of the "open borders" advocate. His overall standpoint remains, one would say "statist": "The principles of public reason that since Plato have been called natural law, natural justice, or natural right suggest and justify a territorial division and assumption of political/state jurisdiction for reasons closely analogous to those that suggest and justify the appropriation of land and other natural and artificial resources to private owners, individual or corporate." ${ }^{22}$ And yet, this assumption is not as radically alternative to the kind open borders position characterized above as it would seem at first sight. This can be observed by considering three other claims advanced by Finnis.

The first is, once again with respect to the issue of "boundaries," that a Thomist such as Francisco de Vitoria, while attributing to indigenous people the status of legitimate state authorities, also held that "they nonetheless are bound by natural justice and the quasi-positive law common to all peoples (ius gentium) to allow well-intentioned travellers into their territories as tourists, missionaries, and traders, and as miners, pearl fishers, and collectors of other kinds of communia or res nullius." ${ }^{23}$ Since Finnis applies the account to contemporary issues, it seems safe to translate it into a right to access the territory, at least temporarily, as "tourists and traders" usually do.

The second claim is quoted from Emer de Vattel: "'no nation may, without good reason, refuse even a perpetual residence to one who has been driven from his country', or to a body of fugitives or exiles unless its own territory 'could scarcely supply the needs of its own citizens.'" 24 And this seems to secure a right to asylum inclusive of a concession of a "perpetual residence" that seems even more demanding than some contemporary interpretations and applications of international refugee law.

The third and more general point recalled by Finnis is well established but even more demanding than the preceding two: the traditional natural law doctrine of the "original commonality of the earth." State sovereignty, analogously to private propriety, is not original but derivative. Both are also not final and serve as the instrument to the ultimate political principle of the common good.

20 J. Finnis, "Commentary on Dummett and Weithman," [in:] Free Movement, p. 203.

${ }^{21}$ It should not be ignored here that the language of rights, despite undoubtedly the lingua franca of moral theory in advanced modernity, is not without critics. Apart from the classic and widely known critiques by Burke, Bentham and Marx, I refer only to R. Geuss, Philosophy and Real Politics, Princeton-Oxford 2008, especially Part II: "Failures of Realism," section: "Rights," p. 70 ff. For a critique with stronger relations with natural law theory, but which anticipates many of Geuss' central arguments, see A. MacIntyre, After Virtue: A Study in Moral Theory, Notre Dame 2007, chapter 6.

${ }^{22}$ J. Finnis, "Boundaries," [in:] J. Finnis, Human Rights and Common Good, pp. 127-128.

23 Ibid., p. 131.

${ }^{24}$ J. Finnis, "Nationality and Alienage," [in:] J. Finnis, Human Rights and Common Good, pp. 139140; quotes from de Vattel are taken from Le Droit des Gens, ou Principes de la Loi Naturelle, appliques a la Conduite et aux Affaires des Nations et des Souverains (transl. C.G. Fenwick), Washington 1916, "Introduction," section 13, and Book I, 231. 
This is an outline of the overall rationale that would comprehend the rights of states and migrants. Thomist qualifications to sovereignty and propriety rights seem to safeguard a right to free movement for "economic migrant" and, more strongly, for the dispossessed. Natural law doctrine seems to imply a more general imperative of justice to establish a migration regime and all other institutional arrangements conducive to the common good of all human beings:

The original commonality of all the earth's resources, as available in justice for all and each of earth's human inhabitants, is abrogated neither by the instituting of private property [...] nor by the appropriation of territories to states; and just as property rights are subject to a kind of moral trust or "social mortgage" (a requirement of justice not merely of charity) for the benefit of the poor in their necessity [...] so the right of states to exclude aliens from their territory is subject in principle to an analogous qualification or burden. ${ }^{25}$

\subsection{MacIntyre on Patriotism and Natural Law}

I would now conclude this review of contemporary thinkers associated with natural law theory engaging with migration by presenting some aspects of MacIntyre's political theory. Strictly speaking, it would be problematic to classify MacIntyre rigidly as a "natural law theorist," and I also believe that it would be reductive to force him into the category of "virtue ethics," but since he presents himself as an Aristotelian Thomist, and that is the tradition to which he contributes, both elements - the virtues and natural law - are undeniably of fundamental importance in his philosophy. A reference to MacIntyre in this context may seem misplaced since he does not treat the issue of migration directly. However, as it will be recalled below, he does intervene on the nature, purpose and limits of the state, and advances considerations about closure, ethno-cultural identity, and relative prejudices, in a way that seems to imply obvious and relevant, even if not specific, implications for migration. A second and stronger reason is the necessity to correct some widespread misreading of MacIntyre's account of patriotism, which is often quoted, including in the literature on migration, as a one-sided if not extreme defence of the claims of community.

If interrogated on the implications of MacIntyre's philosophy in the field of immigration, some people would probably claim that these would favour strict immigration restriction. The name of MacIntyre is often associated with conservatism and, more specifically, "communitarianism."26 Now, what is more, disruptive to communal identity than opening up a society to free migration? To take but a single example, the Stanford Encyclopaedia of Philosophy treats MacIntyre's polit-

${ }^{25}$ Ibid., note 35 .

26 This is, in reality, a political and philosophical school that MacIntyre strongly disavows: "Let me turn now to a very different criticism, that of those defenders of liberal and individualist modernity who frame their objections in terms of the liberalism versus communitarian debate, supposing me to be a communitarian, something that I have never been. I see no value in community as such - many types of community are nastily oppressive - and the values of community, as understood by the American spokespersons of contemporary communitarianism, such as Amitai Etzioni, are compatible with and supportive of the values of the liberalism that I reject"; A. MacIntyre, After Virtue, p. XV. 
ical view in the entry on "Patriotism." There, it is attributed to MacIntyre, coherently with his common reputation of being a relativist, the claim that "There is no morality as such; morality is always the morality of a particular community." Even more: according to MacIntyre, the true patriot, however disagreeing on this or that specific issue within the "project" of patriotic nationality, would be compelled to adhere to the "large interests" of its country in any case, so that "when it comes to those 'large interests' [...] that are beyond criticism and must be supported in an irrational way, his concern will inevitably become exclusive, and most likely aggressive too." 27 On a scale that goes from one to five, MacIntyre comes immediately after Machiavelli's supposed "extreme" patriotism ${ }^{28}$ as the paradigmatic example of "robust" patriotism. The fifth grade of the scale is tellingly named "ethical patriotism," implicitly disclosing, it would seem, a general moral assessment of the preceding categories.

Is this an adequate description of MacIntyre's ideal of allegiance to one's country? Does it follow from that that MacIntyre would oppose or restrict migration, or indeed any other policy, whenever this conflicts with the "large interests" of a community conceived as the primary political good?

I would hold that the answer to both questions is negative. Even without considering that "interest" is not a very pertinent term for a MacIntyrean morality - the central argument of After Virtue is construed in opposition to a morality of arbitrarily conceived interests and bureaucratic efficiency - I would deem important to situate MacIntyre's controversial intervention on patriotism ${ }^{29}$ in its theoretical context and in its proper and defining place in the philosophical itinerary of the author. For it is evident from a careful reading of the essay that MacIntyre is still building on its critique of the abstract and impersonal ethics "in the third person" characterizing modernity. Nonetheless, MacIntyre calls patriotism "a permanent source of moral danger." 30

Thus, the issue is not the difficulty of modern versions of morality in defending an account of patriotism itself but their more general shortcoming in giving an adequate account, for instance, of the particular status, for one, of one's children or one's history or even of oneself. It is the protagonist of this ethics, abstracted from the narrative of life and, consequently, from social relations such as those established in the country one finds oneself to inhabit, that MacIntyre decries as a "citizen of nowhere." 31 But for what regards allegiance to modern nation-state, often qualified in MacIntyre's works as "bureaucratic," shall one expect anything

${ }^{27}$ I. Primoratz, "Patriotism," The Stanford Encyclopedia of Philosophy (Summer 2017 Edition), E.N. Zalta (ed.), https://plato.stanford.edu/archives/sum2017/entries/patriotism/ (accessed: 30.08.2018); emphasis added.

${ }^{28} \mathrm{I}$ am not entirely sure the representation of Machiavelli is objective either, but here I am concerned with the interaction of natural law theory, open borders, and nationalism.

29 A. MacIntyre, "Is Patriotism a Virtue?," [in:] Patriotism, I. Primoratz (ed.), Amherst 2002, pp. 4358. Page numbers quoted here refer to the original version of MacIntyre's lecture given on March 26, 1984 and published by the University of Kansas as the Lindley Lecture, University of Kansas, Lawrence 1984.

30 Ibid., p. 15.

31 Ibid., p. 12. 
different than the critical attitude one can generally suppose in an adherent of supranational political theories such as Marxism and a Thomistic version of the natural law? ${ }^{32}$

If posing the question this way is not sufficient to conjecture an answer, I would hold that two other MacIntyrean sources help to dispel any remaining doubts.

The first is Dependent Rational Animals, in which MacIntyre develops a biologically grounded version of Thomist Aristotelianism according to which the ideological centrality of the artificially self-sufficient healthy and wealthy middle-aged male (but perhaps other restrictions, including of an ethnic kinds, could be appropriately introduced) is rejected in favour of the recognition of interdependence and the vindication of the equal and even exemplary moral standing of the weak and needy: the child, the ill, and, one could legitimately suppose, the migrant.

Perhaps an even more revelatory source is the essay entitled "Natural Law as Subversive," in which MacIntyre details the position of Aquinas with respect to the emerging centralized nation-state. MacIntyre holds that natural law theory would be incompatible with both the earliest statist positivist claims, which pretend that morality and national law are one and the same thing, and with the irrational and intolerant ideas and practices of a populace deprived of social and intellectual structures necessary to recognize moral precepts that go beyond the most immediate general instructions provided by natural law. In this MacIntyre is not only Thomist, but distinctively Aristotelian, in so far as he seems to vindicate the possible success of the Aristotelian attempt, evoked by Finnis, at locating the definition and essence of a community in its politeia (constitution), and not in any other pre-political or extra-political identity. That is, "local prejudice" would find no more place in a MacIntyrean theory than the absolutist authority of the sovereign. The same would hold for a populist combination of the two in so far as it does not leave a place for the rationally binding enterprise of philosophical discovery.

At the same time, any natural law theory must be attentive to preserving the social bonds from disruptive external events. Thus, the requirement usually advanced by anti-immigrationists - that a people has a right not to be "swamped"and which is easily accommodated in a common-sense argument such as that advanced by Michael Dummett, seems also completely compatible with MacIntyre's view of the political good of society. And to those who would argue that this is a contradiction, since openness to strangers and that cultivation of a community's culture cannot be accommodated at the same time, it may be replied that it would be so only if one of these two complementary rights would be made into an absolute and that this would not be a necessity but only a question of "excess." Now,

${ }^{32}$ MacIntyre seems to refer precisely to such wider and superior allegiances when claiming that from the inadequacy of the liberal attachment to one's homeland "it does not follow that some version of traditional patriotism may not be compatible with some other morality of universal moral law, which sets limits to and provides both sanction for and correction of the particularist morality of the patriot. Whether this is so or not is too large and too distinct a question to pursue in this present paper." One of the three examples he provides is that of "patriots and believers in Thomistic natural law," a category to which MacIntyre himself could be seen as claiming to belong, considered his repeated and, after that essay, deepened allegiance to Thomist philosophy. See A. MacIntyre, "Is Patriotism a Virtue?," p. 15. 
moderation and aurea mediocritas ("golden mean") are among the maxims of nat-

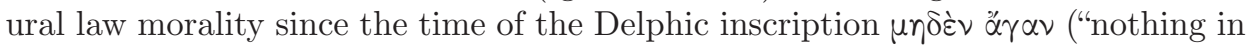
excess"). The way such maxims are to be translated in political practice, however, would depend on a realistic and contextual decision which cannot entirely avoid areas of vagueness, discretion, and controversies.

This way, we are back to something close to the moderate ideal advanced by Aquinas in the Summa Theologiae ${ }^{33}$ where, by explicitly drawing on the Aristotelian Politics, he expounds a concise theory of migration. Excluding hostile relations, which shall be treated according to the doctrine of just war, foreigners are divided into three groups. The first category would be that of people simply crossing borders as travellers (peregrini). The second is the group of people settling among foreigners to work and live there temporarily (advenae). The third case is that of those who want to integrate completely and, to speak with modern terms, "naturalize" (quando aliqui extranei totaliter in eorum consortium et ritum admitti volebant).

Dealing with the first and the second category is reduced to a negative duty of non-interference: travellers and temporary settlers shall not be "molested": impeding passage is not mentioned as a possibility. To me, while recalling again the immense differences in the background conditions - the incommensurably higher level of societal regulations and controls over any population, native or foreign, on health, residence and the like - it seems not unfair to Aquinas's argument to translate it in terms of peaceable hospitality and a general presumption of "open borders." Finally, for the would-be naturalized citizens, Aquinas recommends, referring to Aristotle, that it is possible to wait a certain time in order to avoid that "if foreigners were allowed to meddle with the affairs of a nation as soon as they settled down in its midst, many dangers might occur, since the foreigners not yet having the common good firmly at heart might attempt something hurtful to the people." 34 Populations which are culturally nearer are thus naturalized earlier: Aquinas allows for exceptions in case of heroic and extraordinary civil service. Yet these precepts, as other obligations of justice, extend even "to Ethiopia and to India," since "We ought to treat every human being as, so to speak, neighbour and brother [omnem hominem habere quasi proximum et fratrem]." ${ }^{35}$ On a natural law perspective, the human and political community is thus the most important bond: the evident utopianism of this position is not necessarily a defect:

The rationality of plain persons is to be elicited by and exhibited in their participation in communal practices, practices that require a shared recognition of their common good as a political bond, a type of bond very different from that provided in local societies by ethnic or religious or other prejudice. So Aquinas's theory is as much at odds with local prejudice — as contrasted with local custom - as

${ }^{33}$ T. Aquinas, Summa Theologiae, I-II, 105, 3; I quote from the Benzinger Bros. edition, published in New York in 1947, and also available online.

34 Ibid.

35 T. Aquinas, II-II 78, 1-2, quoted in J. Finnis, "Boundaries," [in:] J. Finnis, Human Rights and Common Good, pp. 129-130, note 4. 
it is with centralizing power. But this may seem to say that it is [...] even deserving to be stigmatized as utopian. I have suggested elsewhere that Utopianism rightly understood is no bad thing. ${ }^{36}$

\section{Conclusions}

As Ann Dummett and Napolitano show, natural law theory is more than two thousand years old and spreads as wide as the Western political thought-possibly even beyond. No less extended is the debate on the naturality of the right to move. In this chapter, after some brief characterizations and specifications, I have discussed a variety of views which are offered as contributions within the natural law tradition on the topic of migration. While recognizing that that is a terminology originally extraneous to natural law vocabulary, I hold that all of them seem compatible with a claim in favour of an open border position, to wit, in defence of a right to international movement. Some of the thinkers I have quoted, such as once again the Dummetts and Napolitano, make that claim explicitly, as does the doctrine of the Catholic Church; others, like Finnis and MacIntyre, offer a theoretical outline in which, I believe, an equivalent to a right to free movement can be identified and translated. In particular, Finnis recalls Vitoria's classical claim - at the time applied to European colonizers - that friendly passengers should not be impeded travelling, even if they are crossing international boundaries. More importantly and more radically, he defends the traditional idea of the common possession of the earth and the limitation of the usage of the private property for the common good. This idea that can hardly be opposed to the right of innocuous foreign workers to enter any country to find employment there, especially if they come from a poorer place. The fact that Finnis is especially attentive at insisting on the qualifications of this and indeed other rights, and his vindication of the sovereign authority of the state, an authority which is meant to serve purposes other than global justice also, does not mean he would not be prima facie in favour of free movement. Such right would obviously come with qualifications, limitations, and a variety of forms of implementation, like any other right of the global application. Finally, I took up the occasion for a clarification on MacIntyre's stance on patriotism and communitarian values to show that every coherent Thomist thinker must be concerned with the politica ${ }^{37}$ character of a community and with the supranational obligations of natural law, including the humane acknowledgement, already explicit in Aquinas, of the immunities of foreigners, and of reasonable practices of naturalization. To conclude, Mehmet Ugur's and James L. Hudson's claims ${ }^{38}$ that natural law theory is overall supportive of open borders appear justified.

${ }^{36}$ A. MacIntyre, "Natural Law as Subversive: The Case of Aquinas," [in:] The Tasks of Philosophy, vol. 1 , p. 63 .

37 This particular view is contentious for Finnis: see note 1.

38 J.L. Hudson,"Philosophy of Immigration," The Journal of Libertarian Studies 8 (1986), p. 53; M. Ugur, "The Ethics, Economics and Governance of Free Movement," [in:] Migration without Borders: 


\section{Bibliography}

Barker R.S., "Natural Law and the United States Constitution," The Review of Metaphysics 66 (2012), pp. 105-130.

Barry B., Goodin R.E. (eds.), Free Movement: Ethical Issues in the Transnational Migration of People and Money, London-New York 1992.

Collier E.W., Strain Ch.R. (eds.), Religious and Ethical Perspectives on Global Migration, New York 2014.

Dummett A., "The Transnational Migration of People Seen from within a Natural Law Tradition," [in:] Free Movement: Ethical Issues in the Transnational Migration of People and Money, B. Barry, R.E. Goodin (eds.), London-New York 1992, pp. 169-180.

Dummett M., On Immigration and Refugees, London 2001.

Finnis J., "Boundaries," [in:] J. Finnis, Human Rights and Common Good, Oxford 2011, pp. 125-132.

Finnis J., "Commentary on Dummett and Weithman," [in:] Free Movement: Ethical Issues in the Transnational Migration of People and Money, B. Barry, R.E. Goodin (eds.), London-New York 1992, pp. 203-210.

Finnis J., "Nationality and Alienage," [in:] J. Finnis, Human Rights and Common Good, Oxford 2011, pp. 133-150.

Finnis J., "Natural Law: The Classical Tradition," [in:] The Oxford Handbook of Jurisprudence and Philosophy of Law, J.L. Coleman, K.E. Himma, S.J. Shapiro (eds.); online publication date: 2012, doi:10.1093/oxfordhb/9780199270972.013.0001.

Geuss R., Philosophy and Real Politics, Princeton-Oxford 2008.

Hendrickson D.C., "Migration in Law and Ethics: A Realist Perspective," [in:] Free Movement: Ethical Issues in the Transnational Migration of People and Money, B. Barry, R.E. Goodin (eds.), London-New York 1992, pp. 213-231.

Hudson J.L., "Philosophy of Immigration," The Journal of Libertarian Studies 8 (1986), pp. 51-62.

Kukathas Ch., "Are Refugees Special?," [in:] Migration in Political Theory, L. Ypi, S. Fine (eds.), Oxford 2016, pp. 249-268.

MacIntyre A., "Is Patriotism a Virtue?," [in:] Patriotism, I. Primoratz (ed.), Amherst 2002, p. $43-58$.

MacIntyre A., The Tasks of Philosophy: Selected Essays, vol. 1, Cambridge 2006.

MacIntyre A., After Virtue: A Study in Moral Theory, Notre Dame 2007.

Napolitano A.P., "Immigration as a Natural Human Right," The Washington Times, 31 January 2013, https://www.washingtontimes.com/news/2013/jan/31/immigration-as-a-natural-human-right/ (accessed: 30.08.2018).

Pius XII, "Radiomessaggio di sua Santità Pio PP. XII per il Santo Natale" [Christmas message 1952], https://w2.vatican.va/content/pius-xii/it/speeches/1952/ documents/hf_p-xii_spe_19521224_natale.html (accessed: 30.08.2018).

Essays on the Free Movement of People, A. Pécoud, P. de Guchtenerie (eds.), New York-Oxford 2007, pp. 65-96. 
Primoratz I., "Patriotism," The Stanford Encyclopedia of Philosophy (Summer 2017

Edition), E.N. Zalta (ed.), https://plato.stanford.edu/archives/sum2017/entries/patriotism/ (accessed: 30.08.2018).

Raymond G., Philosophy and Real Politics, Princeton-Oxford 2008.

Resnick D., "John Locke and the Problem of Naturalization," The Review of Politics 49 (1987), pp. 368-388.

Ugur M., "The Ethics, Economics and Governance of Free Movement," [in:] Migration without Borders: Essays on the Free Movement of People, A. Pécoud, P. de Guchtenerie (eds.), New York-Oxford 2007, pp. 65-96.

Vattel E. de, Le Droit des Gens, ou Principes de la Loi Naturelle, appliques a la Conduite et aux Affaires des Nations et des Souverains, transl. C.G. Fenwick, Washington 1916. 